\title{
Simultaneous acute deep vein thrombosis and acute brucellosis. A case report
}

\author{
Salih Salihi ${ }^{1}$, Şeyda Andaç², Mehmet Kalender ${ }^{3}$, Onur Yıldırım² ${ }^{2}$ Ayfer İmre ${ }^{4}$ \\ ${ }^{1}$ Department of Cardiovascular Surgery, Niğde State Hospital, Niğde, Turkey \\ ${ }^{2}$ Department of Radiology, Niğde State Hospital, Niğde, Turkey \\ ${ }^{3}$ Department of Cardiovascular Surgery, Konya Education and Research Hospital, Konya, Turkey \\ ${ }^{4}$ Department of Infectious Diseases, Niğde State Hospital, Niğde, Turkey
}

Kardiochirurgia i Torakochirurgia Polska 2016; 13 (2): 162-163

\begin{abstract}
Brucellosis is a zoonotic disease common in developing countries. Vascular complications, including arterial and venous, associated with Brucella infection have rarely been reported. A case of deep venous thrombosis (DVT) developing after a diagnosis of acute brucellosis in a young milkman is presented. A 26-year-old man presented with pain in the right leg. The patient's medical history included a diagnosis of brucellosis in our hospital where he had presented with complaints of weakness and fever. Peripheral venous Doppler ultrasound showed DVT, and the patient was treated with anticoagulants. The patient was discharged with warfarin therapy and antibrucellosis treatment. Although rare, some infectious agents may cause vascular pathologies. Patients presenting with symptoms of DVT or similar vascular pathologies should be assessed for infectious agents, particularly in those coming from Brucella-endemic areas.
\end{abstract}

Key words: brucellosis, venous thromboembolism, pulmonary thromboemboli.

\section{Introduction}

Brucellosis is a zoonotic disease of worldwide distribution that mainly affects persons working with domestic animals and animal products. Despite being controlled in many developed countries, the disease remains endemic in many parts of the world, including Latin America, the Middle East, parts of Africa, and western Asia. The clinical presentation can vary from asymptomatic infection with seroconversion to a full-blown clinical picture of fever, night sweats and joint manifestations; occasionally, there is hepatic, cardiac, ocular or central nervous system involvement [1]. Vascular complications, including arteries and veins, associated with Brucella infection have rarely been reported [2].

In this paper, a case of deep venous thrombosis (DVT) developing after a diagnosis of acute brucellosis in a young

\section{Streszczenie}

Bruceloza jest chorobą odzwierzęcą, występującą często w krajach rozwijających się. Niewiele jest doniesień opisujących powikłania naczyniowe (tętnicze i żylne) związane z infekcją bakterią Brucella. W pracy przedstawiono przypadek zakrzepicy żył głębokich, która rozwinęła się po diagnozie ostrej brucelozy u młodego mleczarza. Pacjent w wieku 26 lat zgłosił się z bólem prawej nogi. W badaniu podmiotowym: rozpoznanie brucelozy w naszym szpitalu, do którego pacjent zgłosił się wcześniej z osłabieniem i gorączką. W badaniu USG Doppler żył obwodowych stwierdzono zakrzepicę żył głębokich; pacjent otrzymał leczenie przeciwkrzepliwe. Mężczyznę wypisano z zaleceniem stosowania warfaryny i terapii przeciw brucelozie. Pomimo rzadkości niektóre czynniki infekcyjne mogą powodować patologie naczyniowe. Pacjentów zgłaszających się z objawami zakrzepicy żył głębokich lub podobnych patologii naczyniowych należy ocenić pod kątem czynników infekcyjnych, zwłaszcza jeśli przebywali na obszarach endemicznych dla bakterii Brucella.

Słowa kluczowe: bruceloza, żylna choroba zakrzepowo-zatorowa, płucne zmiany zakrzepowo-zatorowe.

milkman is presented. Apparently, this case report is the second case of DVT due to brucellosis in Turkey.

\section{Case report}

A 26-year-old man presented to our hospital with a 1-week history of pain and swelling in the right leg. He had been dealing with milk. Two hour before, his leg had become swollen and purple. The patient's medical history included a diagnosis of brucellosis 1 week previously in our hospital, where he had presented with complaints of weakness and fever. The Rose-Bengal test was positive; the Brucella tube agglutination test result was 1/160. He was put on rifampicin and doxycycline therapy.

On physical examination, the patient was in a painful condition. Peripheral pulses were weak in the right leg

Address for correspondence: Dr. Salih Salihi, Department of Cardiovascular Surgery, Niğde State Hospital, 51100 Niğde, Turkey, phone: +90 388 2322220, e-mail: drssalihi@yahoo.com 
but strong in the other. The right leg was hot, swollen and purple. The Hoffman test was positive on the right leg. His cardiopulmonary and neurological examinations were unremarkable.

Laboratory analyses revealed the following results: white blood cell count 8,000/ $\mu \mathrm{l}$, hemoglobin $14.2 \mathrm{~g} / \mathrm{dl}$, platelet count $226,000 / \mu \mathrm{l}$, alanine aminotransferase (ALT) $69 \mathrm{U} / \mathrm{l}$, aspartate aminotransferase (AST) $92 \mathrm{U} / \mathrm{l}$. Chest X-ray film disclosed the heart and pulmonary vessels to be of normal size, and electrocardiogram (ECG) showed a sinus rhythm. Color venous Doppler ultrasound of the right lower extremity revealed increased diameter of the right main, deep and superficial femoral veins, the popliteal vein and the cranial segments of the deep crural veins; the lumens of these vessels were occluded with thrombosis. There was no blood flow in the vascular lumen, and there was no response in the veins to compression. The patient was diagnosed with acute deep vein thrombosis. The patient was hospitalized in the Department of Cardiovascular Surgery. Rifampicin 600 mg/day per oral, doxycycline 400 $\mathrm{mg} /$ day per oral and heparin sodium 20000 units/day intravenous in divided doses were administered. He was also given warfarin sodium $5 \mathrm{mg}$ /day per oral simultaneously. Heparin was stopped when the INR values reached a therapeutic level. He was discharged on day seven of hospitalization with regression of complaints and physical examination findings. On discharge, he was prescribed warfarin $5 \mathrm{mg} /$ day, rifampicin $600 \mathrm{mg} /$ day and doxycycline $100 \mathrm{mg} /$ day per oral.

\section{Discussion}

Brucellosis is a systemic infection that can involve any organ or organ system of the body, and since many cases go unrecognized, the true incidence of the disease is unknown [3]. The onset may be sudden, over a few days, or gradual over weeks to months, with nonspecific symptoms including fever, lassitude, malaise, headache, backache, and arthralgia [4]. Sometimes, the manifestations of brucellosis are more pronounced in a specific organ system.

Vascular complications, including arteries and veins, are rare in brucellosis. In a review of articles, reported cases included abdominal artery thrombosis, portal vein thrombosis and cerebral vein thrombosis [2, 4-11]. The disease is mainly transmitted to humans through the ingestion of raw milk or non-pasteurized cheese contaminated with one of the four Brucella species pathogenic to humans. Species causing vascular complications have been identified as B. melitensis, B. abortus and B. suis [5].

Endothelial damage, hypercoagulability, and stasis have been recognized for over 150 years to be the three elements associated with venous thromboembolism (VTE), with often two of these three factors needed for its initiation. Therefore, its etiology is multifactorial, with each component having different impacts on different patients. Brucella infections may cause DVT due to the following mechanisms: invasion of the surrounding tissue by the infectious agent, inflammation caused by the infectious process in the surrounding tissue, direct damage to the endothelium caused by the infectious agent, and temporary hypercoagulopathy caused by the infectious agent [5, 10]. In our patient, there are no abnormal results for the etiological factors that cause thrombosis such as protein C, protein $S$ and anticardiolipin IgG and IgM. We believe that DVT in our patient was associated with Brucella infection, as there were no risk factors for venous thrombosis such as immobilization, history of previous DVT, recent surgical intervention or local tissue trauma.

\section{Conclusions}

Early detection and appropriate treatment of brucellosis are crucial measures to prevent complications of the disease. Patients presenting with symptoms of DVT or similar vascular pathologies should be assessed for infectious agents, particularly in those coming from Brucella-endemic areas.

\section{Disclosure}

Authors report no conflict of interest.

\section{References}

1. Memish ZA, Balkhy HH. Brucellosis and international travel. J Travel Med 2004; 11: 49-55.

2. Colmenero JD, Reguera JM, Martos F, Sánchez-De-Mora D, Delgado M, Causse M, Martín-Farfán A, Juárez C. Complications associated with brucella melitensis infection: a study of 530 cases. Medicine 1996; 75: 195-211.

3. Al Sekait MA. Seroepidemiological survey of brucellosis antibodies in Saudi Arabia. Ann Saudi Med 1999; 19: 219-222.

4. Young EJ, Hall WH. Brucellosis. In: Bacterial infection of humans: epidemiology and control. 3rd ed. Evans AS, Brachman PS (eds.). Plenum Medical Book Company, New York 1998; 155-167.

5. Odeh M, Pick N, Oliven A. Deep venous thrombosis associated with acute brucellosis: a case report. Angiology 2000; 51: 253-256.

6. Sanchez-Gonzales J, Garcia-Delange T, Martos F, Colmenero JD. Thrombosis of the abdominal aorta secondary to Brucella spondylitis. Infection 1996 24: 261-262.

7. Gelfand MS, Kaiser AB, Dale WA. Localized brucellosis: popliteal artery aneurysm, mediastinitis, dementia and pneumonia. Rev Infect Dis 1989; 11: 783-788.

8. Gregori J, Ortuńo J, Ruiz Rivas JL, Arenas M. Brucellosis and portal thrombosis. Rev Esp Enferm Dig 1990; 78: 187-188.

9. Zaidan R, Al Tahan AR. Cerebral venous thrombosis: a new manifestation of neurobrucellosis. Clin Infect Dis 1999; 28: 399-400.

10. Kocak S, Dikmetas C, Dundar Z, Kesli R. Acute deep venous thrombosis associated with acute brucellosis: a case report. JAEMCR 2012; 3: 118-120.

11. Meidani M, Mirzadeh F, Sadeghi A. Simultaneous deep vein thrombosis and acute brucellosis: case report. J Med Sci 2012; 19: 40-42. 